\title{
Exploitation and restoration of bivalve shellfish resources: case studies presented at the Tenth International Conference on Shellfish Restoration
}

\author{
Aad C. Smaal · Jeroen W. M. Wijsman
}

Published online: 6 August 2009

(C) The Author(s) 2009. This article is published with open access at Springerlink.com

In this issue of Aquaculture International a selection of papers that were presented at the Tenth International Conference on Shellfish Restoration (ICSR) is published. The conference was held in November 2007 in Vlissingen, The Netherlands, with over 200 participants from 30 countries. The theme of the conference was broader than shellfish restoration alone: the focus was "innovation in the exploitation and management of shellfish resources." During the conference, six invited speakers gave an overview on various topics within the field of shellfish research. In 80 oral and over 30 poster presentations, organized in 14 sessions, many aspects of shellfish exploitation and management were addressed for 4 days.

The contributions in this issue cover topics related to the culture and exploitation of bivalve shellfish in various parts of the world as well as results of shellfish restoration projects both in the USA and in New Zealand. The possible threat by proliferation of the Pacific oysters is addressed for the Wadden Sea. The outcomes of the conference are summarized in a synthesis paper.

The special issue addresses both aquaculture and ecological topics by case studies from a variety of sites, showing the close link between shellfish aquaculture and ecology. It shows that shellfish culture, shellfish restoration and nature conservation are related issues that need to be addressed in concert in order to achieve a sustainable exploitation.

The cooperation with the ICSR organization in the USA and with Rick DeVoe and Dorothy Leonard in organizing the conference is gratefully acknowledged.

Open Access This article is distributed under the terms of the Creative Commons Attribution Noncommercial License which permits any noncommercial use, distribution, and reproduction in any medium, provided the original author(s) and source are credited.

\footnotetext{
A. C. Smaal $(\bowtie)$

Aquaculture, Imares, P.O. Box 77, 4400 AB Yerseke, The Netherlands e-mail: aad.smaal@wur.nl

J. W. M. Wijsman

Ecology, Imares, P.O. Box 77, 4400 AB Yerseke, The Netherlands
} 


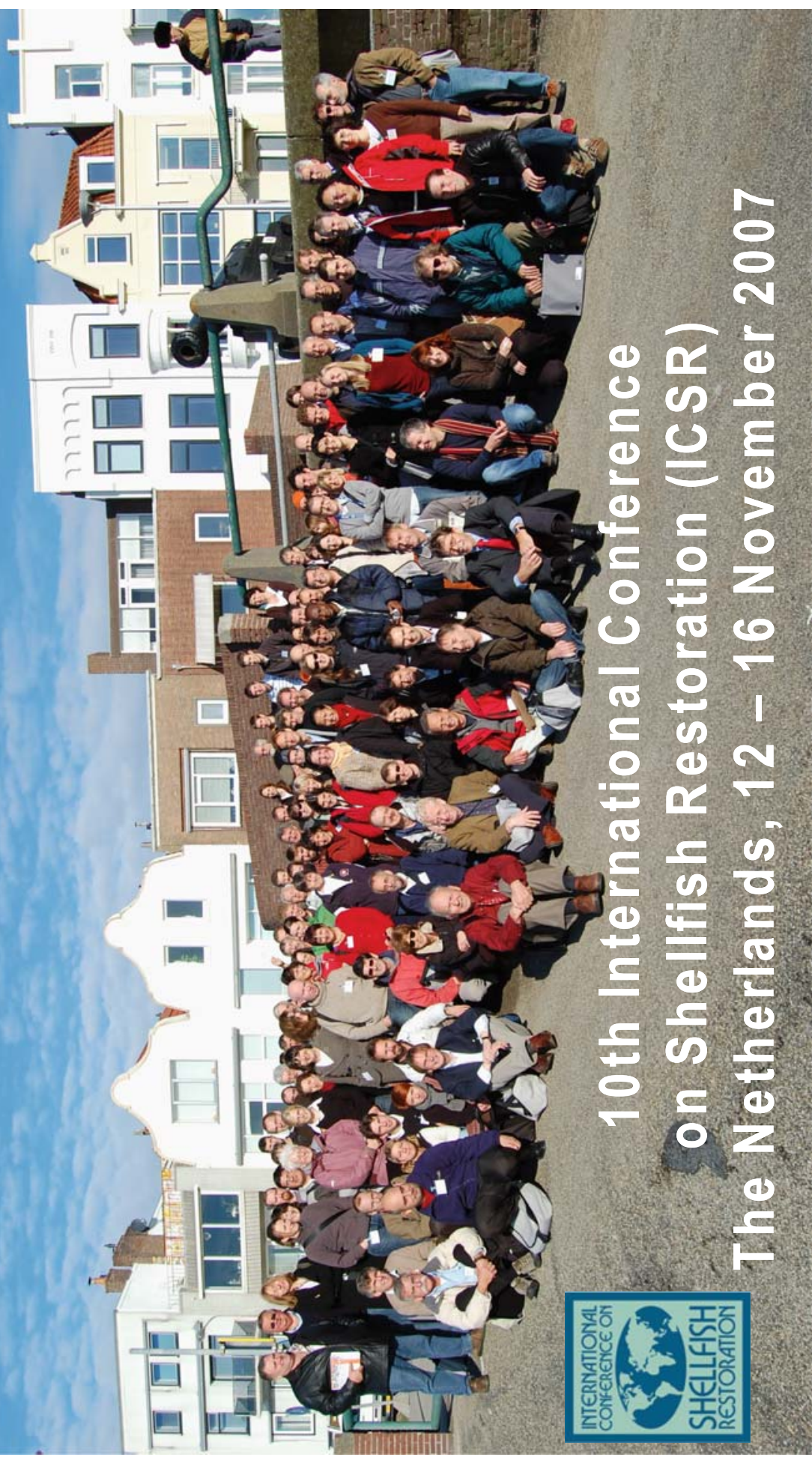

